\title{
Early observations on the health of Syrian refugees in Canada
}

\author{
Hansen $L^{1}$, Maidment $L^{1 *}$, Ahmad $R^{1}$
}

\section{Abstract}

Between November 4, 2015 and February 29, 2016, a total of 26,166 refugees came to Canada. Of those, only two $(0.01 \%)$ were found to have signs of a notifiable disease in the Immigration Medical Examination and these individuals were referred to public health for follow-up. Most refugees - 24,640 (94.17\%) - arrived by government-coordinated charter flights and underwent enhanced screening. Upon arrival in Canada, 274 refugees (1.11\%) were assessed by Quarantine Officers for signs of a potential communicable disease (such as fever) and $10(0.04 \%)$ were referred to hospital. Paramedics onsite at the airport assessed 1,212 refugees $(4.92 \%)$. Fifty-four $(0.22 \%$ ) were transferred to hospital and many of these were known to require urgent medical care.

Provincial and local public health authorities and community networks have been instrumental in providing immediate and longer-term health care to arriving refugees. The two most immediate care needs were catch-up immunizations and dental care. Arriving in Canada at the height of the influenza season, a number of refugees experienced time-limited upper respiratory infections. When referring refugees to Canadian authorities, the United Nations High Commissioner for Refugees (UNHCR) advised that the Syrian refugee population may be expected to have high medical needs. These were not necessarily identified beforehand and may include diabetes, developmental disabilities, conflict-related injuries or mental health issues. These health care needs of Syrians will be identified and addressed as they integrate into the local health care systems.

The arrival of Syrian refugees in Canada has not resulted in any urgent public health concerns or need for public health intervention. Canada's experience to date indicates that the arrival of Syrian refugees in this country can be managed in a way that will integrate them into the health care system without increased risk to public health.

\section{Affiliation}

${ }^{1}$ Health Security Infrastructure Branch, Public Health Agency of Canada, Ottawa, ON

${ }^{*}$ Correspondence: leanne. maidment@phac-aspc.gc.ca

Suggested citation: Hansen L, Maidment L, Ahmad R. Early observations on the health of Syrian refugees in Canada. Can Comm Dis Rep 2016;42-Suppl 2:S8-10. https://doi.org/10.14745/ccdr.v42is2a03

\section{Introduction}

Health considerations figured prominently in Canada's plan to welcome 25,000 Syrian refugees from December 2015 to early 2016. This plan was designed to welcome the refugees and integrate them into the local health care system while protecting Canadians from infectious diseases. Multiple government and non-governmental partners have been working together to implement this plan since the fall of 2015.

The European experience of receiving undocumented and "irregular" migrants in 2015 provided useful information and lessons that Canadian authorities were able to draw upon (1). For example, the European experience demonstrated that refugees from these areas did not pose an infectious disease threat to the domestic population, however they were vulnerable to conditions that spread readily within poor living conditions (2). Unlike in Europe, where the Syrian refugee crisis has meant that thousands of migrants have arrived without prior medical screening or registration, Canada was able to ensure that pre-arrival medical screening was in place. This served to protect public health and also helped connect refugees to the Canadian health care system. 


\section{Welcome Refugees: Health screening}

From December 2015 to February 29, 2016, a total of 26,166 Syrian refugees and their families arrived in Canadian 99 separate flights. Of these, 14,992 refugees were government-sponsored and the remaining 11,174 were privately-sponsored or blended visa office referrals. While all travellers were subject to screening at international airports upon arrival, the health of refugees destined for Canada was also assessed at multiple points prior to arrival.

The Immigration Medical Examination (IME) was conducted prior to travel and assessed all potential immigrants for a short list of communicable diseases of public health importance. If any of these were found and the person remained eligible for refugee status, Immigration, Refugees and Citizenship Canada (IRCC) conveyed this information to local public health authorities in Canada for appropriate follow-up. To date, of the Syrian refugees who have arrived as part of the current resettlement effort, local public health officials were notified of only two individuals with chest $x$ ray results from their IME indicating possible latent (non-infectious) tuberculosis. Local public health will refer these individuals for clinical care and surveillance. IRCC and the Public Health Agency of Canada are collaborating on further epidemiological analysis of the IME data.

In addition to the IME, once the refugees arrived in Canada, they were screened at the point of entry based on the federal government's responsibilities under the Quarantine Act $(3,4)$. Since the first charter flight of Syrian refugees arrived on December 10, 2015, Quarantine Officers at Toronto and Montréal airports who were trained nurses and physicians were on hand for each of the 99 flights carrying an average of 249 passengers. (For a first-hand account from one healthcare professional about this experience, see article by D'Amour in this issue [5].). Arriving passengers who appeared ill or had the potential of having a communicable disease were referred to Quarantine Officers for a more detailed evaluation with the support of an interpreter. Most of those identified were children who arrived after a long international flight with fevers, cough or vomiting. To date, Quarantine Officers assessed 274 Syrian refugees (approximately $1 \%$ ). Of those, ten were referred to local hospitals for further assessment and care and none had a communicable disease of public health concern.

Quebec and Ontario provincial medical teams were stationed at airport Welcome Centres to provide urgent care and assessed approximately 1,212 refugees (4.9\%). In most cases, the emergency medical assistance teams were able to offer care on the spot and only 54 refugees were transferred to hospital. The physicians who accompanied the refugees on their charter flights to Canada were aware of travellers who had pressing health issues such as kidney disease and facilitated referrals to clinics and hospitals upon arrival (A Boucard, personal communication 25 January 2016).

The health status information of Syrian refugees upon arrival to Canada is summarized in Table 1.
Table 1: Initial health status of Syrian refugees in Canada, November 4, 2015 to February 29, 2016

\begin{tabular}{|c|r|r|}
\hline \multicolumn{1}{|c|}{ Characteristic } & Number & Percent \\
\hline Total number of refugees & 26,166 & $100.00 \%$ \\
\hline Government-sponsored & 14,992 & $57.30 \%$ \\
\hline Privately-sponsored & 11,174 & $42.70 \%$ \\
\hline Notifiable disease identified in IME & 2 & $0.01 \%$ \\
\hline HIV & 0 & $0 \%$ \\
\hline Latent TB & 2 & $0.01 \%$ \\
\hline Syphilis & 0 & $0 \%$ \\
\hline Enhanced screening upon arrival ${ }^{\star}$ & 24,640 & $94.17 \%$ \\
\hline $\begin{array}{l}\text { Assessed by Quarantine officer for signs of } \\
\text { infection }\end{array}$ & 274 & $1.11 \%$ \\
\hline Referred to local hospital & 10 & $0.04 \%$ \\
\hline Required urgent care by paramedics & 1,212 & $4.92 \%$ \\
\hline Transferred to hospital & 54 & $0.22 \%$ \\
\hline
\end{tabular}

*From chartered flights between Dec. 10, 2015 - Feb. 29, 2016

\section{Meeting the health needs of Syrian refugees}

Health care providers in Canada have been working together to ensure a coordinated approach to addressing the ongoing health needs of Syrian refugees. The two provinces where Syrian refugees first arrived (Ontario and Quebec), have activated comprehensive health sector plans for refugee reception and resettlement $(6,7)$. Local public health departments have geared up to meet the two greatest initial needs for Syrian refugees: Catch-up vaccinations and urgent dental care (8-10). The Canadian Collaboration for Immigrant and Refugee Health (CCIRH) has developed a checklist (11) which provides evidence-based recommendations for family physicians (12).

Gaps or delays in receiving health care have occurred due to delays in finding permanent housing for government-sponsored refugees in some instances and local challenges in delivery. Nonetheless, the decision by the initial provinces accepting refugees to waive the three-month waiting period for provincial health care insurance and the high degree of collaboration by local providers, have facilitated the integration of refugees into the Canadian health care system.

There is limited specific evidence on the health status of asylum seekers and refugees. Dr. Anna Banerji, a pediatric infectious disease specialist in Toronto who provided care to Syrian refugee families in immigrant reception centres in the period immediately following their arrival, observed that up to one third of refugee children suffered from common viral illnesses, such as upper respiratory tract, ear and throat infections and gastrointestinal illness. There was an influenza outbreak among 450 Syrian refugees who arrived in Edmonton, Alberta at the end of January 2016 (12). They arrived at the height of the influenza season and before they could all receive the influenza vaccine, approximately half the adults and most of the children became ill (13). These infections resolved with time and supportive care.

Consistent with the experience in the European Union, major mental health issues have not been identified to date among 
the Syrian refugees. Post-traumatic stress disorder is likely to emerge over the long term, as refugees become settled in their new lives and are able to mentally process the stresses of war, displacement and loss. Cultural psychiatrists in Ontario and Quebec are providing e-consultations as part of an effort to build capacity for culturally sensitive mental health services across the country.

It is expected that chronic medical conditions will be revealed over time. Out of fear, refugees may under-report health issues in the assessment process (14), and it is expected that in otherwise 'healthy' refugees who have undergone the IME, 5\% may have some form of ongoing health care need (M MacKinnon, personal communication 25 January 2016). In referring refugees to Canadian authorities, the United Nations High Commissioner for Refugees (UNHCR), advised that the Syrian refugee population could be expected to have "high medical needs". These needs may include diabetes, developmental disabilities and conflict-related injuries. The pediatrician in the immigrant reception centre in Toronto agreed with the IRCC estimate and has found conditions ranging from seizures and developmental disorders, to blood transfusion dependent thalassemia and childhood cancers (A Banerji, personal communication 25 January 2016). The Co-Chair of the CCIRH has noted that malnutrition has been observed, and physicians have identified a number of children with intellectual disabilities, although it is too early to identify whether this is higher than the average incidence in North America. A pediatric surveillance system is being established to monitor this ( $K$ Pottie, personal communication 22 February 2016).

\section{Conclusion}

Large-scale refugee movements place pressure on health care systems, both in their immediate response and as part of long-term resettlement efforts. As Syrians integrate into Canada, meeting their longer-term health care needs will call for a seamless network of health care providers, supported by community partners. It will also require the ongoing commitment of government and academia to build the capacity of the health system by training the right people using the best available technology and monitoring for emerging issues.

Canada's experience in recent weeks has illustrated that no major communicable disease concerns have arisen to date. As anticipated, Syrian refugees who have arrived in Canada have some outstanding health needs. The health sector is working to address these needs, while health care providers and the general population can rest assured that minimal risks have been posed to the public health.

\section{Conflict of interest}

None.

\section{References}

1. European Centre for Disease Prevention and Control. Communicable disease risks associated with the movement of refugees in Europe during the winter season - 10 November 2015. Stockholm: ECDC; 2015.

2. Catchpole $M$, Coulombier D. Refugee crisis demands European Union-wide surveillance! Eurosurveillance. 2015;20(45):2-3.

3. Government of Canada. Quarantine Act S.C. 2005, c.20. http://lawslois.justice.gc.ca/eng/acts/q-1.1/FullText.html.

4. Bhatia N, Sarwal S, Robinson H, Geduld J, Huneault F, Schreiner H, Collins S, Hickey R. Federal public health strategies to minimize the importation of communicable diseases into Canada. Can Comm Dis Rep 2015;41-Suppl 6:S3-8.

5. D'Amour R. My experience as a Quarantine Officer welcoming Syrian refugees. Can Comm Dis Rep 2016;42-Suppl 2:S11-2.

6. Ontario Ministry of Health and Long-Term Care. Ontario Health System Action Plan: Syrian refugees, December 17, 2015. Toronto: MOHLTC; 2015. http://www.health.gov.on.ca/en/pro/programs/ emb/syrianrefugees/docs/health_system_action_plan.PDF.

7. Plan d'action du gouvernement du Québec pour l'accueil et l'intégration des personnes réfugiées sélectionnées à l'étranger 2013-2016. (Available in French only: https://www. immigration-quebec.gouv.qc.ca/publications/fr/divers/PLA_ AccueilRefugies2013-2016.pdf).

8. Toronto Public Health. Staff report: Response to Syrian refugee health needs. January 11, 2016. http://www.toronto.ca/legdocs/ $\mathrm{mmis} / 2016 / \mathrm{hl} / \mathrm{bgrd} /$ backgroundfile-88528.pdf.

9. City of Toronto Public Health. Refugee resettlement program. Toronto: City of Toronto; 2016. http://www1.toronto.ca/wps/portal/ contentonly?vgnextoid=93614790451 a1510VgnVCM10000071 d60 f89RCRD.

10. Refugee 613. Health toolkit for refugees: Ottawa Specific2015/2016. Ottawa ON: Ottawa Newcomer Health Centre and Somerset West Community Health Centre; 2015. http://www.swchc. on.ca/sites/default/files/Refugee_Health_Toolkit_2015-2016.pdf.

11. The Canadian Collaboration for Immigrant and Refugee Health. Evidence-based preventative care checklist for new immigrants and refugees. Ottawa: CCIRH; 2016. http://www.ccirhken.ca/ccirh/ checklist_website/index.html.

12. Pottie K, Greenaway C, Hassan G, Hui C, Kirmayer L. Caring for a newly arrived Syrian refugee family. CMAJ. 2016;Epub.151422.

13. Syrian refugees hit by first flu season in Canada. Canadian Broadcasting Company. January 22, 2016. http://www.cbc.ca/ news/canada/edmonton/syrian-refugees-hit-by-1st-flu-season-incanada-1.3415254.

14. O'Donnell CA, Higgins M, Chauhan R, Mullen K. Asylum seekers' expectations of and trust in general practice: A qualitative study. $\mathrm{Br}$ J Gen Pract J R Coll Gen Pract. 2008;58(557):e1-11.

\section{Acknowledgements}

We would like to thank and acknowledge all the people who have been part of the effort to welcome Syrian refugees to Canada. 